\title{
Tectonic Shifts: Foreword
}

Claire Omhovère

\section{(2) OpenEdition}

1 Journals

Electronic version

URL: https://journals.openedition.org/ces/7843

DOI: $10.4000 /$ ces. 7843

ISSN: 2534-6695

\section{Publisher}

SEPC (Société d'études des pays du Commonwealth)

\section{Printed version}

Date of publication: 1 September 2011

Number of pages: 5

ISSN: 2270-0633

\section{Electronic reference}

Claire Omhovère, "Tectonic Shifts: Foreword", Commonwealth Essays and Studies [Online], 34.1 | 2011,

Online since 16 November 2021, connection on 01 December 2021. URL: http://

journals.openedition.org/ces/7843; DOl: https://doi.org/10.4000/ces.7843

\section{(c) (i) (5)}

Commonwealth Essays and Studies is licensed under a Licence Creative Commons Attribution - Pas d'Utilisation Commerciale - Pas de Modification 4.0 International. 


\section{Foreword}

Marta Dvorak stepped down from the editorship of Commonwealth Essays and Studies after the special issue devoted to Janet Frame's short fiction she co-edited with Christine Lorre in the spring of 2011. Our journal has greatly benefited from the energy and the imagination Marta has brought to its direction in the past six years. Under her congenial supervision, Commonwealth Essays and Studies has grown stronger, acquiring an even wider readership, in print as well as on line through the global aggregator ProQuest.

The transition with the new editorial team has been a smooth one thanks to Christine Lorre who has kindly accepted to guest-edit the present issue and to look after the reviews section in collaboration with Kerry-Jane Wallart, from 34.2 onwards. I am also grateful for the support received from our international advisory board whose participation in the vetting process of submissions guarantees the quality of the articles we choose to publish.

Claire OMHOVÈRE, general editor 